УДК 347.73

DOI https://doi.org/10.32849/2663-5313/2020.7.42

\title{
Тарас Пасъко,
}

аспірант кафедри міжнародного, європейського права

та иивільно-правових дисииплін

Навчально-наукового інституту права

Сумсъкого державного університету

\section{ПОНЯТТЯ, ПРАВОВІ ОЗНАКИ ТА ВИДИ НЕВИЇЗНИХ ПОДАТКОВИХ ПЕРЕВІРОК В УКРАЇНІ}

Автором статті з'ясовано, що з урахуванням звіту ДПС Украйни починаючи з 2020 р. одним із основних способів наповнення дохідної частини бюджету заплановано використання контрольно-перевіряльної роботи. Проаналізовано підходи науковщів до визначення податкової перевірки як основної форми податкового контролю. Враховуючи закріплений нормативно перелік способів такого контролю в Україні, визначено, що перевірка є формою, а не методом податкового контролю. Досліджено підходи окремих учених до класифікачії податкових перевірок. Автором статті на основі наявних у Податковому кодексі Украйни дефініиій податкових перевірок визначено три види перевірки, які можна віднести до невиїзних, а також виділено й проаналізовано основні риси (особливості), які вирізняють вказаний вид перевірок від інших. Такими рисами є: 1) місце проведення; 2) прочедура призначення та проведення; 3) необов'язковість присутності платника податків. Під час проведення аналізу першої риси невиїзої перевірки з'ясовано, шо чинне податкове та інше законодавство не містить визначення поняття «приміщення контролюючого органу», а також інформачію, щодо приміщення якого саме контролюючого органу має використовуватись для проведення вказаної форми контролю. Автором за результатами дослідження та аналізу чинного податкового законодавства й нормативних актів у сфері будівниитва визначено, що невиїна перевірка має проводитись у приміщенні територіального органу податкової служби за місцем обліку платника. Одночасно автором дослідження запропоновано внесення змін до Податкового кодексу Украӥни в частині заміни наявного словосполучення «приміщення контролюючого органу» на слова «будівля державного органу». Проведена характеристика другої та третьої рис дала змогу підкреслити особливість невиїзих перевірок, на відміну від виїзних, з огляду на відсутність необхідності дотримання суворішої процедури підготовки та ї̈ проведення. За результатами проведеного аналізу нормативно-правових актів та з урахуванням позичій учених у галузі податкового права автором сформульовано власне визначення «невиїза податкова перевірка».

Ключові слова: класифікація, камеральна перевірка, електронна перевірка, місце проведення, приміщення контролюючого органу.

Постановка проблеми. Дотримання норм податкового законодавства $є$ необхідною умовою забезпечення успішного впровадження реформ в економіці. Держава в особі контролюючих органів має забезпечити налагодження механізму взаємовідносин, який дасть змогу платникам податків належним чином виконувати покладені на них податкові обов'язки.

Таким механізмом у нашій державі $\epsilon$ податковий контроль, ефективне проведення якого сприятиме систематичному наповненню дохідної частини бюджету держави.

Незважаючи на широкий перелік способів податкового контролю, основним і найбільш дієвим методом залишається податкова перевірка.

Враховуючи, що для підготовки та проведення виїзних податкових перевірок вимагаються значні затрати робочого часу, тру- дових ресурсів, а також чітке дотримання процедури допуску посадових осіб, можна вважати, що саме невиїзні перевірки є головним важелем у процесі підвищення ефективності роботи органів податкової служби.

При цьому зараз дефініція невиїзної перевірки (загальне визначення) та податкової перевірки в Податковому кодексі України відсутні. Вказаний кодекс також не містить окремих норм, з яких можна чітко встановити критерії класифікації перевірок.

Прогалини в правовому регулюванні зазначеного способу податкового контролю зумовлює вчинення помилок, які опосередковано впливають на рівень ефективності податкових органів і правової захищеності платників податків.

Аналіз останніх досліджень і публікацій. У різні часи проблемам організації податкового контролю та окремих його способів 
присвячено праці Н.А. Маринів, Д.М. Реви, О.О. Яковенка, Т.Г. Детюка та Ю.О. Соловйової.

На формування наукової позиції автора також мали вплив напрацювання Р.О. Єни та Д.В. Тиновського.

Постійне законодавче реформування контрольно-перевіряльної діяльності держави загалом та органів, уповноважених на іiї проведення, зокрема, а також відсутність окремої наукової праці, присвяченої визначенню поняття правових ознак та видів невиїзних податкових перевірок, вказують на потребу у проведенні цього дослідження.

Метою статті $€$ аналіз сутності, ознак та особливостей законодавчого регулювання проведення невиїзних податкових перевірок, визначення їхніх видів і місця в системі перевірок, що здійснюються податковою службою, виявлення недоліків нормативно-правового регулювання та формування пропозицій, спрямованих на вдосконалення норм податкового законодавства.

Виклад основного матеріалу. Серед базових категорій вітчизняного податкового права однією з ключових є категорія «податкового контролю».

Згідно 3 п. 61.1 ст. 61 Податкового кодексу України (далі - ПКУ), податковий контроль - це система заходів, що вживаються контролювальними органами та координуються центральним органом виконавчої влади, який забезпечує формування та реалізацію державної фінансової політики 3 метою контролю правильності нарахування, повноти та своєчасності сплати податків і зборів, а також дотримання законодавства 3 питань регулювання обігу готівки, проведення розрахункових та касових операцій, патентування, ліцензування та іншого законодавства, контроль за дотриманням якого покладено на контролювальні органи.

Ст. 62 ПКУ закріплено способи здійснення податкового контролю:

- ведення обліку платників податків;

- інформаційно-аналітичне забезпечення діяльності контролювальних органів;

- проведення перевірок і звірок відповідно до вимог ПКУ, а також перевірок щодо дотримання законодавства, контроль за дотриманням якого покладено на контролювальні органи, у порядку, встановленому законами України, що регулюють відповідну сферу правовідносин;

- моніторинг контрольованих операцій та опитування посадових, уповноважених осіб та/або працівників платника податків згідно із ст. 39 ПКУ.
Державною податковою службою України в лютому 2020 р. за результатами аналізу доходів загального фонду державного бюджету від податків і зборів (з урахуванням сум відшкодованого ПДВ) за січень 2020 р. заплановано та здійснено акцент на тому, що в першому кварталі 2020 р. виконання дохідної частини бюджету буде забезпечено завдяки таким заходам, як підвищення ефективності системи моніторингу відповідності податкових накладних критеріям оцінки ступеня ризиків, підвищення якості контрольно-перевіряльної роботи, підвищення якості аналізу заявлених до відшкодування сум ПДВ та якості складання матеріалів камеральних і документальних перевірок, посилення боротьби із незаконним обігом підакцизних товарів (тютюну, алкоголю, пального), вжиття заходів податкового контролю в частині дотримання роботодавцями трудового законодавства з метою забезпечення додаткових надходжень до бюджетів шляхом легалізації найманої праці та детінізації заробітної плати [1].

Тобто центральним органом виконавчої влади, який реалізує державну податкову політику, наголошено, що з метою забезпечення формування централізованих державних грошових фондів завдяки надходженню від податків і зборів пріоритетним способом податкового контролю є проведення перевірок (камеральних і документальних).

Аналіз Податкового кодексу України та інших нормативно-правових актів дає змогу вказати, що нині визначення податкової перевірки нормативно не врегульовано.

Зокрема, М.П. Кучерявенко зазначає, що податкова перевірка $€$ основним методом податкового контролю. Вчений вказує, що податкова перевірка являє собою діяльність податкових органів з аналізування і дослідження первинної облікової та звітної документації, пов'язаної зі сплатою податкових платежів, з метою перевірки своєчасності і повноти сплати податків і зборів, правильного ведення податкового обліку, обчислення сум податкових платежів, здійснення податкової звітності [2, с. 240].

Н.А. Маринів уважає, що податкова перевірка - це урегульована нормами матеріального й процесуального права діяльність спеціально уповноважених контролювальних державних органів із контролю за дотриманням платниками порядку й строків нарахування, утримання, сплати податків і зборів (обов'язкових платежів) і надання податкової звітності, яка проводиться на підставі аналізу й дослідження первинної облікової та звітної документації, пов'язаної зі сплатою податків і зборів (обов'язкових платежів) [3, с. 126]. 
Ю.В. Гаруст зазначає, що податкова перевірка є діяльністю податкових органів з аналізу й дослідження первинної облікової та звітної документації, пов'язаної зі сплатою податкових платежів, з метою перевірки своєчасної та повної сплати податків і зборів, правильного ведення податкового обліку, обчислення сум податкових платежів, здійснення податкової звітності [4, с. 6].

3 урахуванням викладеного можна зазначити про відсутність єдиного підходу до визначення поняття «податкової перевірки».

Враховуючи, що згідно з положеннями ст. 62 ПКУ перевірка $€$ одним із способів податкового контролю, а не прийомом для встановлення об'єктивних даних щодо повноти та своєчасності сплати податків і зборів, податкову перевірку доцільно розглядати як форму податкового контролю.

Ст. 75 ПКУ, зокрема пп. 75.1, передбачено, що контролюючі органи мають право проводити три види перевірок: камеральні, документальні й фактичні.

Науковці сходяться на думці про відсутність нині узгодженості в науковій класифікації перевірок. Учені пропонують здійснювати поділ невиїзних перевірок за різними критеріями.

Ю.В. Гаруст поділяє податкові перевірки на: камеральні, виїзні, комплексні, тематичні, тактичні, зустрічні, планові, позапланові, повторні, формальні, оперативні [4, с. 6].

На думку Д.М. Реви, перевірки можна поділити на камеральні, виїзні (планові та позапланові ), повторні, а також ті, що здійснюються за зверненням платника податків або проводяться відповідно до кримінальнопроцесуального законодавства [5, с. 93].

Зі свого боку I.M. Васькович і М.М. Баран класифікують податкові перевірки за декількома підставами: за обсягом контрольованих дій (камеральні, документальні, фактичні та зустрічні); залежно від періодичності проведення документальної перевірки (планові, позапланові) і залежно від місця проведення документальних перевірок (виїзні і невиїзні) [6, с. 204].

Д.В. Тиновський зазначає, що з урахуванням положень ПКУ в Україні нормативно закріплено два види виїзних податкових перевірок - документальна (планова та позапланова) й фактична [7, с. 308].

М.П. Кучерявенко під час класифікації податкових перевірок одним із критеріїв поділу зазначає місце проведення. Науковець у межах цього поділу виділяє виїзну та камеральну перевірки. При цьому остання $€$ перевіркою, що проводиться органом податкового контролю за місцем його розташування [2, с. 243].
Спираючись на положення ст. ст. 75-78 ПКУ, до невиїзних податкових перевірок можна віднести камеральну перевірку, невиїзну документальну (планову або позапланову) та позапланову невиїзну електронну перевірку.

Такий поділ здійснено на основі нормативно визначених дефініцій останніх.

Зокрема, відповідно до пп. 75.1.1 п. 75.1 ст. 75 ПКУ, камеральною вважається перевірка, яка проводиться у приміщенні контролювального органу виключно на підставі даних, зазначених у податкових деклараціях (розрахунках) платника податків, та даних системи електронного адміністрування податку на додану вартість (даних центрального органу виконавчої влади, що реалізує державну політику у сфері казначейського обслуговування бюджетних коштів, в якому відкриваються рахунки платників у системі електронного адміністрування податку на додану вартість, даних Єдиного реєстру податкових накладних і даних митних декларацій), а також даних Єдиного реєстру акцизних накладних і даних системи електронного адміністрування реалізації пального.

Документальною невиїзною перевіркою вважається перевірка, яка проводиться в приміщенні контролювального органу (пп. 75.1.2 п. 75.1 ст. 75 ПКУ). Особливості проведення документальної невиїзної перевірки врегульовано положеннями ст. 79 ПКУ.

Згідно з абз. 7 пп. 75.1 .2 п. 75.1 ст. 75 ПКУ, документальною невиїзною позаплановою електронною перевіркою за заявою платника податків вважається перевірка, що проводиться на підставі заяви, поданої платником податків із незначним ступенем ризику, визначеним відповідно до п. 77.2 ст. 77 ПКУ, до контролюючого органу, в якому він перебуває на податковому обліку.

3 огляду на зазначені вище дефініції доцільно виокремити та проаналізувати декілька основних ознак, які відрізняють невиїзні податкові перевірки від інших.

Першою ознакою є місце проведення. Невиїзні перевірки проводяться в приміщенні контролювального органу (органу податкової служби).

При цьому в ПКУ не зазначено приміщення якого саме органу податкової служби має використовуватись під час проведення перевірки. Також ПКУ не містить поняття «приміщення контролювального органу».

Спираючись на системний аналіз п. 63.3 ПКУ, п. 7 положення «Про Державну податкову службу України», затвердженого Постановою Кабінету Міністрів 
України від 6 березня 2019 р. № 227, та п. п. 1.2, 1.3 Порядку обліку платників податків і зборів, затвердженого Наказом Міністерства фінансів України від 9 грудня 2011 р. № 1588, можна зробити висновок, що органом, уповноваженим на проведення невиїзних податкових перевірок, є відповідний територіальний орган центрального органу виконавчої влади, що реалізує державну податкову політику, в якому перебуває на обліку платник податків.

При цьому актуальним залишається визначення поняття «приміщення контролювального органу».

У ст. 14 ПКУ закріплено перелік понять, що вживаються в кодексі, та їхнє значення. Серед зазначених термінів, а також в інших статтях поняття «приміщення контролюючого органу» відсутне.

Згідно $з$ положеннями п. 6.1 Наказу ДФС України від 16 листопада 2018 р. № 739 «Про затвердження документів, які регламентують діяльність ЦОП», проєктування нових або реконструкції старих будинків, споруд і комплексів, а також вбудовано-прибудованих приміщень, призначених для обслуговування платників, здійснюється згідно з вимогами, встановленими державними будівельними нормами ДБН В.2.2-17:2006 «Будинки і споруди. Доступність будинків і споруд для маломобільних груп населення», ДБН В2.2-9-99 «Громадські будинки та споруди. Основні положення», ДБН 360-92** «Містобудування. Планування і забудова міських і сільських поселень».

Наказом Міністерства регіонального розвитку та будівництва України від 28 вересня 2018 р. № 260 на заміну ДБН В2.2-9-99 «Громадські будинки та споруди. Основні положення» затверджено нові ДБН - В.2.29:2018 «Громадські будинки та споруди. Основні положення».

Згідно з положеннями вказаних норм, останні містять визначення (дефініції) «приміщення 3 постійним перебуванням людей» та «приміщення технічні». Водночас дефініція «приміщення контролювального органу» відсутня.

При цьому пп. 14.1.15 п. 14.1 ст. 14 ПКУ закріплено визначення будівлі. Згідно з дефініцією останньої, це земельні поліпшення, що складаються з несучих та огороджувальних або сполучених (несучо-огороджувальних) конструкцій, які утворюють наземні або підземні приміщення, призначені для проживання або перебування людей, розміщення майна, тварин, рослин, збереження інших матеріальних цінностей, провадження економічної діяльності.
Визначення типу будівель здійснюється Державним комітетом України зі стандартизації, метрології та сертифікації, який Наказом від 17 серпня 2000 р. № 507 затвердив Державний класифікатор будівель і споруд ДК 018-2000.

Згідно 3 класифікацією будівель і споруд за їхнім функціональним призначенням, відповідно до Наказу від 17 серпня 2000 р., будівлі органів державного та місцевого управління (код 1220.1) належать до класу «Будівлі офісні» ( код 1220).

Одночасно варто наголосити, що Наказом Національного агентства України 3 питань державної служби від 3 березня 2016 р. № 50 затверджено Типові правила внутрішнього службового розпорядку, які визначають загальні положення щодо організації внутрішнього службового розпорядку органу державної влади, іншого державного органу, його апарату, режим роботи, умови перебування державного службовця в органі державної влади та використання його робочого часу.

У п. п. 7 та 8 вказаного Наказу використовується поняття «адміністративна будівля державного органу». Також у вказаних пунктах врегульовано порядок інформування працівником керівника у разі виходу з вказаної будівлі та порядок виконання завдань поза їі межами.

Отже, з огляду на відсутність нині нормативно визначених понять «приміщення» та «приміщення контролювального органу», доцільно останнє словосполучення в ПКУ замінити словами «будівля державного органу».

Другою ознакою є процедура призначення та проведення невиїзних перевірок. Умови та порядок допуску посадових осіб контролювальних органів до проведення документальних виїзних і фактичних перевірок визначено ст. 81 ПКУ. Положеннями вказаної статті врегульовано умови та дії, під час дотримання яких працівники податкових органів можуть провести виїзні перевірки. Однією з обов'язкових умов $€$ пред’явлення (надіслання) наказу про проведення перевірки.

При цьому непред'явлення або не надіслання у випадках, визначених ПКУ, платнику податків (його посадовим (службовим) особам або його уповноваженому представнику, або особам, які фактично проводять розрахункові операції) документів, вказаних е п. 81.1 ст. 81 ПКУ, або пред’явлення зазначених документів, що оформлені з порушенням вимог, встановлених цим пунктом, є підставою для недопущення посадових (службових) осіб контролювального органу 
до проведення документальної виїзної або фактичної перевірки.

На відміну від виїзних перевірок, під час проведення невиїзних перевірок дотримання такої процедури не передбачається.

Наприклад, вимогу про вручення наказу про проведення перевірки з повідомленням дати ії початку передбачено лише у разі проведення документальної позапланової невиїзної перевірки (п. 79.2 ст. 79 ПКУ).

Водночас камеральна перевірка проводиться посадовими особами контролювального органу без будь-якого спеціального рішення керівника такого органу або направлення на її проведення.

Щодо електронної перевірки, то підставою її проведення є самостійне ініціювання iii проведення платником податків шляхом подання заяви, тобто фактично надання згоди на їі проведення. В такому випадку керівник контролювального органу протягом 10 календарних днів із дня отримання заяви приймає рішення про проведення / не проведення електронної перевірки.

Третя ознака - присутність платника податків під час проведення перевірки.

Згідно з пп. 17.1.6 п. 17.1 ст. 17 ПКУ платники податків мають право бути присутнім під час проведення перевірок та надавати пояснення з питань, що виникають під час таких перевірок, і за власною ініціативою - пояснення з питань, що не запитувалися контролювальним органом.

При цьому, на відміну від виїзних перевірок, під час проведення яких так чи інакше присутні посадові особи платника податків, що перевіряється (або його представник та) або особа, що фактично здійснюе розрахункові операиії - $n .80 .7 \mathrm{~cm} .80$ ПКУ), під час проведення документальної невиїзної перевірки або камеральної, присутність платників податків необов'язкова.

Вказане твердження підтверджується п. 79.3 ст. 79 та п. 76.1 ст. 76 ПКУ

\section{Висновки}

Враховуючи вищевикладене, можна запропонувати таке визначення невиїзної податкової перевірки: це спосіб податкового контролю, який проводиться в будівлі державного (податкового) органу за ініціативою платника податків або органу ДПС та полягає у здійсненні комплексу дій із перевірки своєчасності подання податкових декларацій (розрахунків), своєчасності реєстрації податкових або акцизних накладних (розрахунків коригування до них), виправлених у них помилок, своєчасності сплати узгодженої суми податкового (грошового) зобов'язання, перевірки своєчасності, достовірності, повноти нарахування та сплати податків і зборів, а також дотримання валютного та іншого законодавства на підставі податкових декларацій, даних, що перебувають у розпорядженні податкового органу та інших документів, наданих платником податків незалежно від способу їх подання.

\section{Список використаних джерел:}

1. Виконання Державною податковою службою держбюджету за січень 2020 року. Державна податкова служба Украйни. Офіиійний портал. URL: https://tax.gov.ua/media-tsentr/ novini/406706.html (дата звернення: 03.06.2020).

2. Кучерявенко М.П. ін. Фінансове право : підручник / за ред. М.П. Кучерявенка. Харків : Право, 2013. 398 с.

3. Маринів Н.А. Податкова перевірка як організаційно-правова форма реалізації податкового контролю : дис. ... канд. юрид. наук : 12.00.07. Харків, 2007. 227 с

4. Гаруст Ю.В. Правове забезпечення контрольної діяльності податкових органів України : автореф. дис. ... канд. юрид. наук : 12.00 .07 . Ірпінь, 2008. $20 \mathrm{c}$.

5. Рева Д.М. Правове регулювання податкового контролю в Україні : дис. ... канд. юрид. наук : 12.00.07. Харків, 2005. 230 с.

6. Васькович I.M. Податковий аудит в системі державного контролю України. Вісник Наиіонального університету «Львівська політехніка». 2012. № 739. C. 201-206.

7. Тиновський Д.В. Поняття та предмет виїзної податкової перевірки як виду податкових перевірок. Науковий вісник Дніпропетровського державного університету внутрішніх справ. 2012. № 2. C. 302-309.

Taras Pasko. Concept, legal signs and types of on-site tax audit in Ukraine

The author of the article found that based on the report of the State Tax Service of Ukraine, starting from 2020, one of the main ways to fill the revenue part of the budget is planned to use control and audit work. The approaches of scientists to the definition of tax audit as the main form of tax control have been analyzed. Given the normative list of methods of such control in Ukraine, it was determined that the audit is a form, not a method of tax control. The approaches of separate scientists to classification of tax checks are investigated. The author of the article, based on the definitions of tax audits available in the Tax Code of Ukraine, has identified three types of audits that can be attributed to on-site and highlighted and analyzed the main features (peculiarities) that highlight the said type of audits of others. Such features are: 1) location; 2) procedure of appointment and conduction; 3) optional presence of the taxpayer. When analyzing the first trait of an on-site audit it is established that the current tax and other legislation does not contain 
the definition of "the placement of the controlling body", as well as information regarding the placement of which the controlling body should be used to conduct the said form of control. According to the results of the research and analysis of the current tax legislation and regulations in the construction sphere, the author has determined that the on-site inspection should be conducted in the premises of the territorial body of the tax service at the payer's place of registration. At the same time, the author of the research proposed amendments to the Tax Code of Ukraine in terms of replacement of the existing phrase "placement of the controlling authority" with the words "building of the state authority". The characteristics of the second and third features made it possible to emphasize the peculiarity of on-site inspections, as opposed to on-site inspections, given that there was no need to follow a strict preparation and implementation procedure. Based on the results of the conducted analysis of regulatory legal acts and taking into account the positions of scientists in the field of tax law, the author has formulated his own definition of "on-site tax audit".

Key words: classification, desk audit, electronic audit, location, rooms of the supervisory authority. 